\title{
Direct and indirect assessment of the amount of naturally occurring asbestos in fractured rocks
}

\author{
F. Piana ${ }^{(1)}$, L. Barale ${ }^{(1)}$, S. Botta ${ }^{(2)}$, R. Compagnoni( ${ }^{(3)}$, C. Fidelibus ${ }^{(4)}$, \\ S. Tallone ${ }^{(1)}$, C. Avataneo ${ }^{(2)}$, R. Cossio ${ }^{(3)}$, F. Turci $^{(5)}$ \\ (1) Institute of Geosciences and Earth Resources, National Research Council of Italy, Torino, Italy. \\ fabrizio.piana@cnr.it; luca.barale@igg.cnr.it; sergio.tallone@csg.to.cnr.it \\ (2) Gi-Res S.R.L., Torino, Italy. \\ serenabotta09@gmail.com; c.avataneo@unito.it \\ (3) Department of Earth Sciences, Università di Torino, Italy. \\ roberto.compagnoni@unito.it; roberto.cossio@unito.it \\ (4) Dipartimento di Ingegneria dell'Innovazione, Università del Salento, Lecce, Italy. \\ corrado.fidelibus@unisalento.it \\ (5) Department of Chemistry, Università di Torino, Italy. \\ francesco.turci@unito.it
}

\begin{abstract}
Naturally-Occurring Asbestos (NOA) may constitute a severe health risk when metamorphic rocks are excavated for large infrastructure projects. For public acceptance, a reliable assessment of the content of NOA is necessary for the design of the construction site, workers' safety, and spoil management. Direct measurements of NOA content can be made by SEM-EDS analyses on an adequate number of samples. Such measurements are sufficiently precise but questions about the representativity of the samples may arise, especially when the rock units are structurally and lithologically complex. Therefore, in order to corroborate the direct assessments, alternative and indirect assessments can be performed by measuring the fracture volumetric porosity, provided that almost all the NOA is deposited as veins in the fractures of the rock mass. Statistical sampling and inference procedures can be applied to derive such an index. In this paper, an indirect assessment of NOA is reported and compared with the assessment obtained by direct measurements. The application is to a metamorphic rock formation through which a tunnel is to be driven as part of the "Gronda di Genova" highway development in Genoa, Italy. Even though significant approximations are made, the indirect assessment is relatively close to the direct measurement.
\end{abstract}

Keywords: asbestos, Naturally Occurring Asbestos (NOA), fractured rocks, Discrete Fracture Networks (DFNs), fracture sampling.

\section{Estimación directa e indirecta del contenido de depósitos de minerales de amianto en rocas fracturadas}

\begin{abstract}
RESUMEN
El asbesto de origen natural (NOA) puede constituir un grave riesgo para la salud cuando se excavan rocas metamórficas para grandes proyectos de infraestructuras. Para la aceptación pública, una evaluación confiable del contenido de NOA es necesaria para el diseño del sitio de construcción, la seguridad de los trabajadores y la gestión de los residuos. Las medidas directas del contenido de NOA son factibles por medio de SEM-EDS. Estas medidas son bastante precisas, pero surgen preguntas relacionadas con la representatividad de las muestras, especialmente cuando las unidades rocosas sometidas a excavaciones son estructuralmente y litológicamente complejas. Por lo tanto, para corroborar las evaluaciones directas, si el asbestos se deposita como venas en las fracturas de la masa rocosa, se pueden realizar evaluaciones alternativas e indirectas midiendo la porosidad volumétrica de fracturacion. Muestreos estadísticos y procedimientos de inferencia pueden aplicarse para derivar este índice. En esta nota, con referencia a una formación de roca metamórfica en el sistema infraestructural de la "Gronda di Genova", Italia, se presenta una evaluación indirecta de NOA y se compara con la evaluación obtenida a través de medidas directas. Aunque se introducen grandes aproximaciones, la evaluación indirecta es relativamente buena.
\end{abstract}

Palabras clave: amianto, NOA, rocas fracturadas, redes de fracturas discretas (DFN), muestreo de fracturas. 


\section{Introduction}

Metamorphic fractured rocks may contain asbestos minerals in fractures. Significant environmental problems may arise when these rock formations are excavated for the construction of tunnels. The "Gronda di Genova" project (NW Italy) is a 72km-long bypass highway that includes $54 \mathrm{~km}$ of tunnels, around $50 \%$ of which are in potentially asbestiferous rocks (meta-ophiolitic units). The estimated amount of spoils resulting from the excavations is about 11 million cubic metres (ASPI, 2011), a large part of which is expected to contain Naturally-Occurring Asbestos (NOA) minerals, namely chrysotile (Ctl) and actinolite-tremolite amphiboles (Act-Tr) in concentrations greater than the legal limit $(1000 \mathrm{mg} / \mathrm{kg})$ fixed by the Italian authorities. As the disposal of these spoils is costly, assessments of NOA content by various methods have been undertaken from the first design stages and reported in the literature (Giacomini et al., 2010; Turci et al., 2015). Recently, an experimental campaign, framed into a research project funded by SPEA Engineering S.p.A. (in charge of the preliminary design of the project), was undertaken to combine direct measurements, in the form of quantitative analyses on about two hundred rock samples using Scanning Electron Microscopy/ Energy Dispersive X-Ray Spectroscopy (SEM-EDS), and indirect measurements consisting of a statistical analysis of the fracture network in an ophiolite outcrop along the "Gronda di Genova" layout, in order to assess the fracture porosity. The rationale for the indirect measurements is that asbestos minerals originated mainly in veins and fractures and that, once the asbestos concentration in fractures is estimated, the fracture porosity can be used to derive the overall asbestos content.

In this paper, the indirect measurements are described, and the results obtained in terms of asbestos content are compared with the results obtained by using the direct measurements. The paper is organized in the following sections: the geological setting of the "Gronda di Genova" area, the direct measurements of NOA mineral content, the fracture network data, the derivation of the fracture porosity and the subsequent indirect calculation of the NOA content. A discussion of the quality of the assessment by the indirect measurements is given in the conclusion section.

\section{Geological setting}

The Genoa area lies in the 'interference zone' (sensu Piana et al., 2017) between the Alps and Apennines orogenic systems. As shown in Figure 1, the geological units crossed by the "Gronda di Genova" are, from West to East (Capponi and Crispini, 2008; Capponi et al., 2016):

- the Voltri ophiolitic massif, consisting of meta-ophiolites and the relevant meta-sedimentary covers; it includes two tectono-metamorphic units, the Voltri and the Palmaro-Caffarella unit;

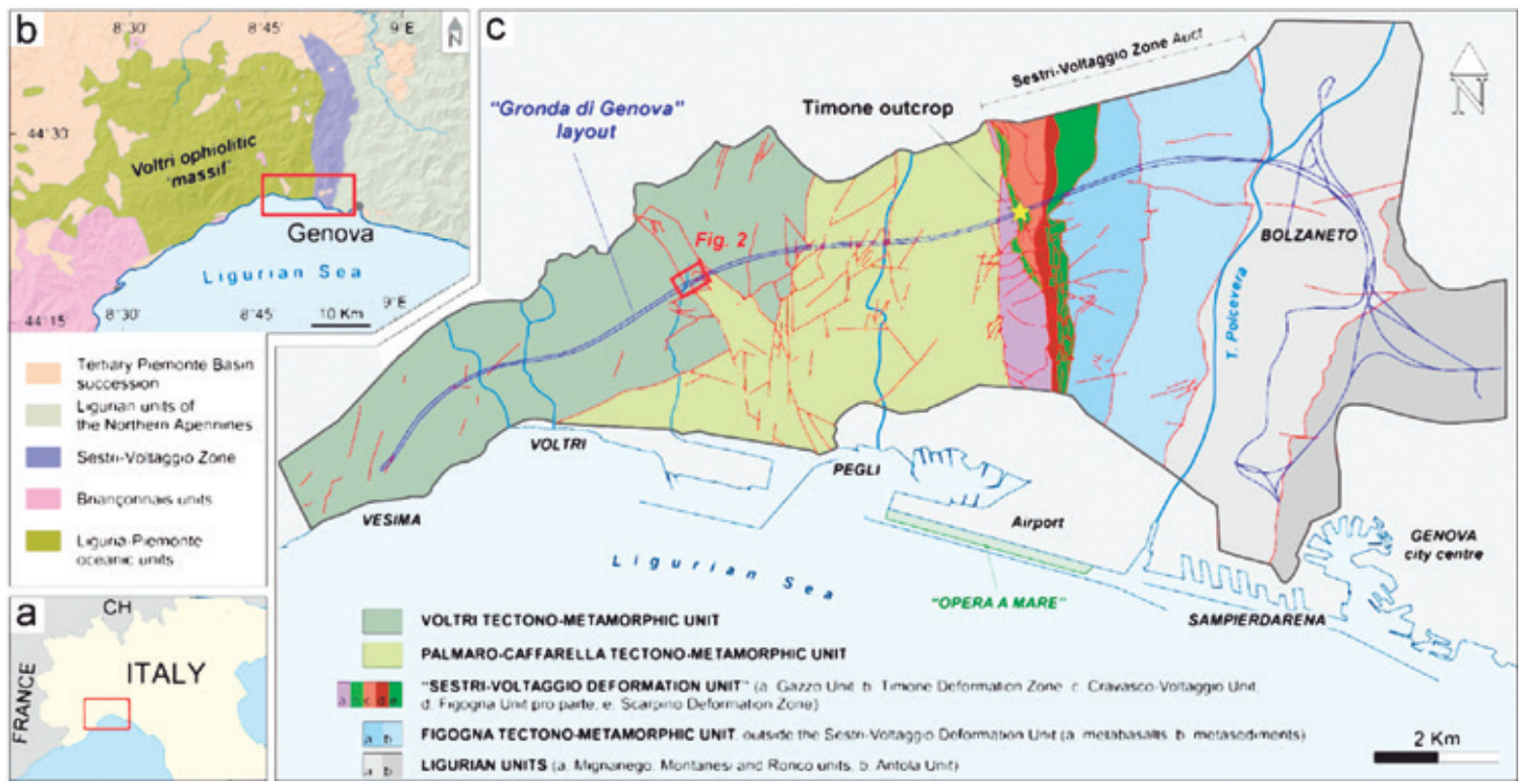

Figure 1. a) the Genoa area in NW Italy. b) simplified geological scheme of the Genoa area. c) Geological scheme along the "Gronda di Genova" layout, showing the position of the investigated serpentinite outcrop at Timone.

Figura1. a) el área Genoa en el NW de Italia. b) esquema geológico simplificado del área de Genoa. c) Esquema geológico a lo largo de la "Gronda di Genova", mostrando la posición del afloramiento de serpentinita estudiado en Timone. 


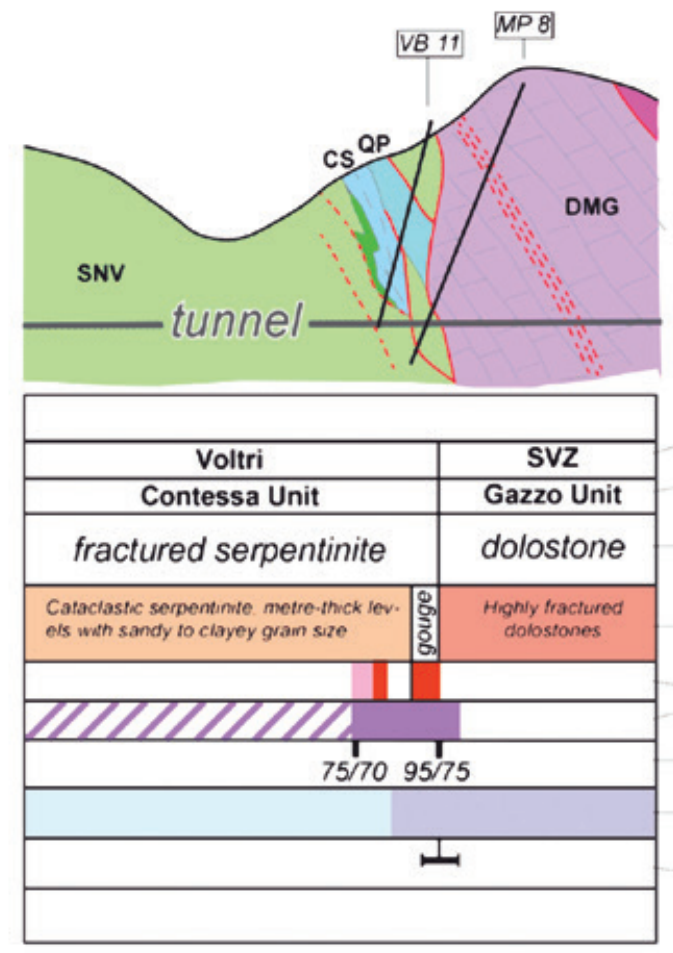

\begin{tabular}{|c|c|}
\hline $2 \mathrm{~b} 1,2 \mathrm{~d} 1$ & 4 \\
\hline $55 \%$ & 0 \\
\hline NOA ZONE 6c & NOA ZONE 7 \\
\hline 17 samples & nO NOA \\
\hline
\end{tabular}

\section{General geological information}

\section{tectonometamorphic unit}

lithotectonic unit

lithology

fracturation degree

fault rocks

- fault orientation

degree of interpretation

error bar for contact position

NOA information

- NOA petrofacies

- $\mathrm{ACR}_{\mathrm{z}}$, Asbestos Content Ratio

NOA homogeneous zone

number of analyzed samples

Figure 2. Excerpt from the geological section along the "Gronda di Genova" main tunnel (southern tube, location in Figure 1). The geological section is accompanied by a table summarising the main geological information, including NOA information in the last four rows (the Asbestos Content Ratio indicates the estimated percentage of rocks above the NOA legal limit over the total rock volume of each tunnel segment). Modified from Botta et al., 2020.

Figura 2. Extracto de la sección geológica a lo largo del túnel principal de "Gronda di Genova" (tubo sur, localización en Figura 1). La sección geológica está acompañada de una tabla que resume la información geológica principal, incluyendo información NOA en los últimos cuatro años (el Ratio de Contenido en Asbestos indica el porcentaje estimado de rocas por encima del límite NOA legal sobre el volumen total de roca en cada segmento del túnel). Modificado de Botta et al., 2020.

- the Sestri-Voltaggio zone, a kilometre-long tectonic slice zone, made up of different tectono-metamorphic units with both meta-ophiolitic and non-ophiolitic sequences;

- the Ligurian meta-sedimentary units.

All these formations underwent a multi-phase tectono-metamorphic evolution; early phases (D1, D2) of isoclinal to tight folding gave rise to the regional foliation whereas later phases (D3, D4) generated multi-scale folds, associated with reverse faults and shear zones (Capponi and Crispini, 2008).

The Voltri-massif and the Sestri-Voltaggio-zone units are superposed along a N-S striking deformation zone, the Sestri-Voltaggio line, along which rocks pert
NOA minerals, namely chrysotile (Ctl) and actinolite-tremolite amphiboles (Act-Tr), are widespread in the meta-ophiolites of the Voltri and Palmaro-Caffarella units and in some tectonic units of the Sestri-Voltaggio Zone.

\section{Methodology for estimating asbestos along the tunnel segments}

Potentially asbestiferous rocks were first investigated by petrographic analyses, consisting of the description of the asbestos-bearing veins in terms of composition, thickness and occurrence of fibrous and elongated/acicular minerals. They were coupled with 
micro-Raman spectroscopy to provide a reliable distinction of mineral species, namely the three serpentine polymorphs (lizardite, antigorite, chrysotile; e.g. Rinaudo et al., 2003; Groppo et al., 2006). The lithological groups were then classified by the asbestos content detected by quantitative analyses using Scanning Electron Microscopy/Energy Dispersive X-Ray Spectroscopy (SEM-EDS). These steps led to the definition of some NOA petro-structural facies ("NOA petrofacies" in the following), i.e. classes of rock sharing specific lithological, structural and NOA content features. NOA petrofacies with NOA minerals above the legal limit include serpentinites and serpentinite breccias, actinolite/tremolite-chlorite schists (SAC) and fault rocks developed at the expense of serpentinites (Botta et al., 2020). Following the identification of these NOA petrofacies, the tunnels were subdivided into NOA-homogeneous zones, i.e. tunnel segments characterized by the occurrence of a specific NOA petrofacies or an association of few NOA petrofacies. The asbestos content was estimated for each of the NOA-homogeneous zones based on the occurrence and distribution of the NOA petrofacies. Figure 2 shows the estimated asbestos contents reported against the geological sections of the main tunnel, together with other geological information.

\section{Analysis of the test case}

The indirect assessment of the asbestos content comprises: 1) the geometric characterization of the fracture system and of the veins containing asbestos; 2) the 3D modelling of their occurrence and extension within the rock mass; 3 ) the assessment of the total fracture/vein area per unit volume and subsequent cal- culation of the NOA content per unit volume. The final result of the procedure was compared to the actual asbestos content measured in the rock mass by cores of three-metre length from drill holes oriented in three almost mutually-orthogonal directions.

The procedure was tested on a large outcrop of cataclastic lizardite serpentinites belonging to the Cravasco-Voltaggio tectono-metamorphic unit of the Sestri-Voltaggio Zone, nearTimone in the Genoa hinterland (coordinates: $44^{\circ} 27^{\prime} 33.0^{\prime \prime} \mathrm{N}$; $8^{\circ} 50^{\prime} 56.9^{\prime \prime} \mathrm{E}$; Figure 1c).

These rocks are crossed by different vein generations, which were characterized by optical microscopy and micro-Raman spectroscopy on petrographic thin sections. Older veins, cemented by lizardite opaque minerals, are cut by chrysotile veins. Polyphasic veins with lizardite at the core and chrysotile at the margins are also present.

\section{Direct assessment}

The actual concentrations of NOA minerals in the Timone outcrop were measured in samples obtained from three drill cores, roughly perpendicular to each other, and from the same outcrop (VB10, MP7 e MT). Samples for quantitative analyses were obtained by grinding three portions of the drill cores, each one metre long. The samples were crushed and ground to a fine powder in the laboratory of the Institute of Environmental Geology and Geoengineering of the National Research Council of Italy in Rome, following the procedures recommended in the relevant Italian regulations (D.L. 152/2006 and D.M. 161/2012). For each sample, a representative portion of the ground powder (about $16 \mathrm{~g}$ ) was analysed by SEM-EDS at the

\begin{tabular}{|c|c|c|c|c|}
\hline sample & filter & NOA concentration [ppm] & error [ppm] & number of fibres \\
\hline \multirow[t]{4}{*}{ VB10-25.00/-26.00 } & $\mathrm{a}$ & 258 & 86 & 66 \\
\hline & $\mathrm{b}$ & 972 & 535 & 81 \\
\hline & $\mathrm{c}$ & 6281 & nd & 9 \\
\hline & $d$ & 416 & nd & 9 \\
\hline \multirow[t]{4}{*}{ M.T. $-2.00 /-3.00$} & $a$ & 111 & 76 & 24 \\
\hline & $\mathrm{b}$ & 271 & 120 & 50 \\
\hline & c & 75 & nd & 2 \\
\hline & $d$ & 39 & nd & 2 \\
\hline \multirow[t]{4}{*}{ MP7-10.00/-11.00 } & $a$ & 80 & 20 & 103 \\
\hline & $\mathrm{b}$ & 2889 & 1344 & 129 \\
\hline & $\mathrm{C}$ & 0 & 0 & 0 \\
\hline & d & 28 & nd & 2 \\
\hline
\end{tabular}

Table 1. Results of SEM-EDS quantitative analyses of drill-core samples from the Timone outcrop.

Tabla 1. Resultados del análisis cuantitativo SEM-EDA de las muestras de testigo de sondeo del afloramiento Timone. 
Interdepartmental Centre "G. Scansetti" of Università di Torino to quantify the NOA content. For each powder sample, four distinct subsamples were analysed (named filter $a, b, c, d$ ). The NOA concentrations in Table 1 are expressed in parts per million (ppm); the error and the number of counted fibres (for an area of about $1 \mathrm{~mm}^{2}$ ) are also indicated.

Based on the results shown in Table 1, a weighted mean NOA concentration of $750 \mathrm{ppm}$ was assumed to be representative for theTimone outcrop. This concentration, assuming a mean density of the lizardite serpentinite rock of $2750 \mathrm{~kg} / \mathrm{m}^{3}$, corresponds to a measured weight of NOA minerals of $2.063 \mathrm{~kg}$ per cubic metre of rock.

\section{Indirect assessment}

The results of the statistical analysis of the fractures would comprise the input to a Discrete Fracture Network (DFN) model (although the model was not used in the study reported here), and the input to the estimation of the asbestos content. This estimation, as per the methodology described below, was compared with the results of the quantitative chemical analyses of the samples and the core segments of the MV, MP7 and VB10 boreholes, drilled at the test site.

The statistical characterization of a fracture system in a rock mass is difficult due to time constraints and various operational difficulties. However, the use of statistical methods in engineering problems in fractured rock applications is gaining acceptance among scientists and practitioners. The objective of the statistical characterization is to define probability density functions (PDFs) of the geometrical parameters of the fractures, which are represented as planar objects. A by-product of the statistical analysis is a DFN model, i.e., an assembly of planar figures of given shape, whose orientation and dimensions are extracted from the pre-defined PDFs. The number of fractures per volume in a DFN is given by the measured fracture intensity. If the fractures of the rock mass are relatively persistent, the secondary porosity of the rock mass is strongly dependent on the fracture intensity, provided that a mean value (or a PDF) is ascribed to the fracture apertures. In the following, the results of a statistical analysis of the rock mass of the "Gronda di Genova" is reported. As the purpose of the analysis was to determine the secondary porosity, an analytical inference procedure was applied and there was no need to generate DFNs.

The statistical analysis required the collection of a sufficient number of data from the selected observational sampling window (the outcrop); the data comprised fracture orientations and the lengths and intensities of the fracture traces. The traces are the intersections of the fractures on the outcrop and these measured intersections are two-dimensional. The statistical analysis, however, requires three-dimensional traces, which are inferred by using stereological concepts and pre-defined fracture shapes. The steps for defining the secondary porosity were:

1. survey the selected outcrop and provide a preliminary definition of the fracture sets and the relative orientations;

2. take digital photographs of the outcrop;

3. create a digital file of the photographs;

4. draw the fracture traces on the digital file;

5. measure the in-situ orientations of some of the traces detected in the digital file;

6. measure a statistically-significant number of orientations on traces in the digital file;

7. define the fracture sets by using the data from steps 4 and 5 with reference to the results of step 1 .

8. attribute sets to traces by visual inspection of the digital file; and

9. calculate the cumulative trace length for each set in the digital file.

The fracture sets are defined on a stereographic plot of the fracture poles. Clustering of poles can generally be done using methods based on the automatic analysis of the angular distances between the poles; a Fuzzy clustering method was used for this study. The Fisher isotropic distribution was used as the PDF of the orientations. For a fracture set with a given dip and dip direction of the normal of the mean fracture plane and an angular variation of $\delta$ with respect to this normal, Fisher's distribution is:

$$
f(\delta)=\frac{\kappa \sin \delta e^{\kappa \cos \delta}}{e^{\kappa}-e^{-\kappa}}
$$

where $\kappa$ is Fisher's constant. As previously mentioned, the objective of the measures is to estimate the fracture intensity for each fracture set. In theory, this can be done for a line, a surface or a volume, i.e., in one, two or three dimensions. Dershowitz and Herda (1992) provided a list of measures of fracture intensities. Among these quantities, $P_{21}$, the length of fractures per unit rock area (or the trace intensity), in $\mathrm{m}^{-1}$, can be directly determined by collecting the cumulative length of the traces on the outcrop and dividing it by the area under observation, as performed in this case. The target quantity is $P_{33^{\prime}}$, the volume of fractures per unit volume of rock mass (or the volumetric porosity), which is the sum of the volumes of the individual fractures divided by the reference volume. The direct experimental determination of $P_{33}$ is obviously not possible. However, it is associated with 


\begin{tabular}{|c|c|c|c|c|c|c|c|c|c|c|}
\hline$\rho$ k & 0.1 & 1 & 2 & 5 & 10 & 50 & 100 & 200 & 500 & $\infty$ \\
\hline 0 & 0.79 & 0.77 & 0.70 & 0.53 & 0.39 & 0.19 & 0.14 & 0.11 & 0.07 & \\
\hline 5 & 0.79 & 0.77 & 0.70 & 0.54 & 0.40 & 0.21 & 0.17 & 0.14 & 0.12 \\
\hline 10 & 0.79 & 0.77 & 0.70 & 0.54 & 0.43 & 0.25 & 0.22 & 0.20 & 0.20 \\
\hline 20 & 0.79 & 0.77 & 0.72 & 0.58 & 0.49 & 0.38 & 0.37 & 0.36 & 0.36 \\
\hline 30 & 0.79 & 0.78 & 0.74 & 0.64 & 0.58 & 0.53 & 0.52 & 0.52 & 0.52 \\
\hline 40 & 0.79 & 0.78 & 0.76 & 0.71 & 0.68 & 0.66 & 0.66 & 0.66 & 0.66 & \multirow{2}{*}{$\sin \rho$} \\
\hline 50 & 0.79 & 0.78 & 0.78 & 0.77 & 0.77 & 0.77 & 0.77 & 0.78 & 0.78 & 0.87 \\
\hline 60 & 0.79 & 0.79 & 0.79 & 0.82 & 0.85 & 0.87 & 0.87 & 0.87 & 0.94 \\
\hline 70 & 0.79 & 0.80 & 0.82 & 0.87 & 0.90 & 0.94 & 0.94 & 0.94 & 0.94 \\
\hline 80 & 0.79 & 0.80 & 0.83 & 0.90 & 0.94 & 0.98 & 0.98 & 0.99 & 0.99 \\
\hline 90 & 0.79 & 0.80 & 0.83 & 0.91 & 0.95 & 0.99 & 0.99 & 1.00 & 1.00 & \\
\hline
\end{tabular}

Table 2. Discrete values of $1 / C_{23}$ as functions of $\kappa$ and $\rho$ (Wang, 2005).

Tabla 2. Valores discretos de $1 / C_{23}$ como funciones de $\kappa$ y $\rho$ (Wang, 2005).

$P_{32}$, which is the area of fractures per unit volume of rock mass (or the volumetric intensity), defined as the sum of the areas of the individual fractures divided by the reference volume. Although $P_{32}$ cannot be directly measured, it can be inferred from $P_{21}$ by using simplifying hypotheses for the shape and orientation of the discontinuities. Among many contributions, Wang (2005) provided a relationship to determine $P_{32}$ as a function of $P_{21}$ by using a coefficient $C_{23}\left(P_{32}=C_{23} P_{21}\right)$ that is independent of the size of the fractures if they are of equal size (or are infinitely persistent); the coefficient depends on the Fisher constant $\kappa$ and on the angle $\rho$ between the mean normal of the fracture set and the normal of the sampling window. Table 2 gives the values of $1 / C_{23}$ as reported by Wang (2005). Even though the fractures in this study are not of equal size, Wang's relationship is used as this is only a preliminary evaluation. More appropriate hypotheses for the size distribution are necessary in order to perfect the assessment of $P_{32}$.

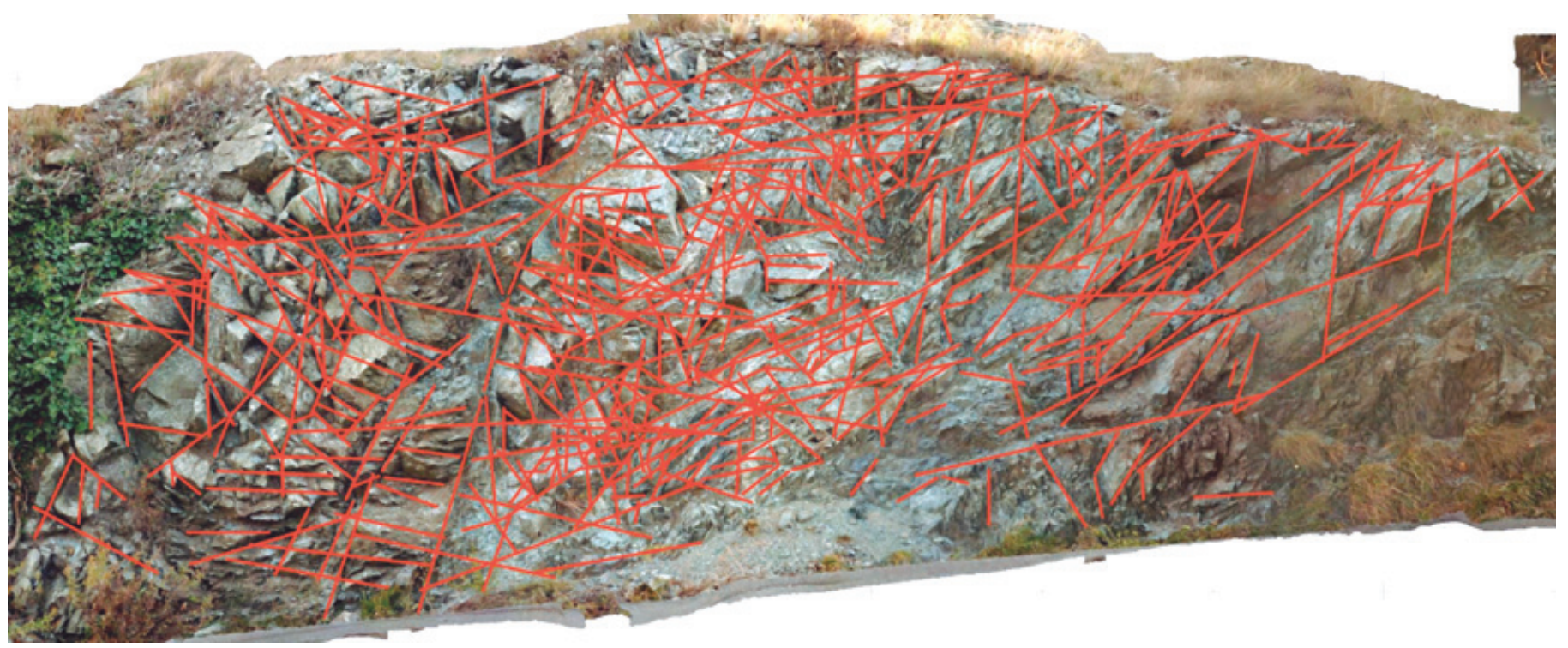

Figure 3. Pattern of traces automatically derived by analysis of the digital model.

Figura 3. Patrón de trazas derivado automáticamente mediante el análisis del modelo digital. 


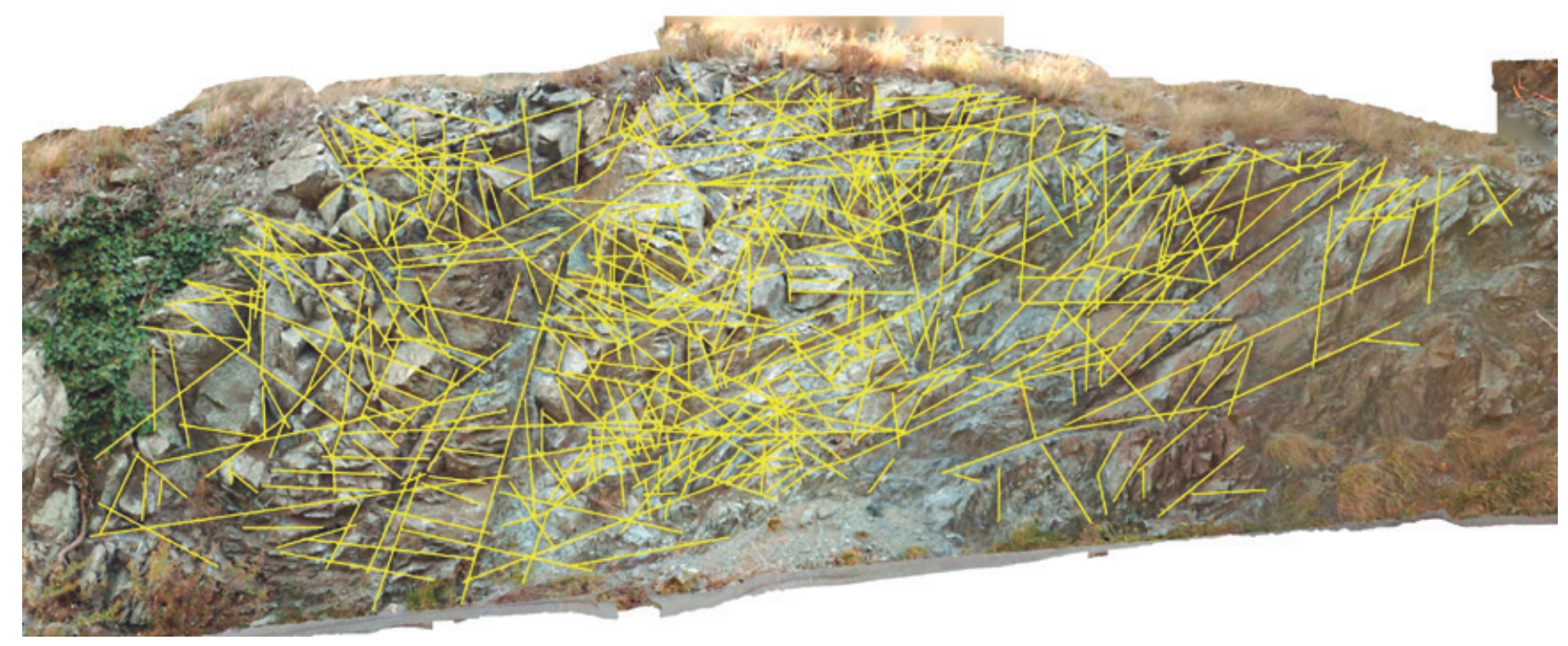

Figure 4. Traces drawn manually on the digital model of the outcrop.

Figura 4. Dibujo manual de las trazas sobre el modelo digital del afloramiento.

After a first survey to define of the fracture sets, the outcrop was surveyed with a laser scanner to produce a 3D digital model of the outcrop. Semi-automatic methods have the advantage of allowing the measurement of fractures even in sectors not physically accessible by the operators (e.g., at high altitudes compared to the base plan). Traces were manually drawn on the digital model and the relative orientations were measured for a significant number of them. The structural associations were then used to assign the fracture sets defined in the first survey to each trace. The fracture sets were then condensed into macro-sets by analysing the stereographic plots (not reported here) and the Fisher distribution was defined for each macro-set. $P_{32}$ was defined for each macro-set using Table
2 and the cumulative lengths. An approximate value of the volume of asbestos contained in the rock mass was obtained by multiplying these values by the mean value of the aperture and the saturation of asbestos in the fractures. Figure 3 shows the traces derived from the digitized points using the Gexcel srl Reconstructor software. The software creates a mesh of triangles from the points of the digital model and then calculates the dihedral angle between pairs of contiguous triangles. The points selected are those for which the dihedral angle is within $90^{\circ} \pm \Delta$ where $\Delta$ is a small tolerance. The sensitivity of the results to values of $\Delta$ was checked. The traces in Figure 3 were manually refined by visually inspecting the digitized photo after an additional on-site survey (Figure 4). In spite of this

\begin{tabular}{|c|c|c|c|c|c|c|c|c|c|c|}
\hline & \multicolumn{2}{|c|}{ mean pole } & \multicolumn{3}{|c|}{ direction cosines } & & & & & \\
\hline MS & trend & plunge & $I$ & $m$ & $n$ & $\rho$ & $\mathrm{K}$ & $P_{21}$ & $1 / C_{32}$ & $P_{32}$ \\
\hline 1 & 288 & 26 & -0.85 & 0.28 & -0.44 & 90.5 & 12.1 & 2.50 & 0.95 & 2.63 \\
\hline 2 & 237 & 49 & -0.55 & -0.36 & -0.75 & 57.3 & 50.1 & 2.25 & 0.82 & 2.74 \\
\hline 3 & 232 & 18 & -0.75 & -0.59 & -0.31 & 40.1 & 52.7 & 1.09 & 0.64 & 1.70 \\
\hline 4 & 195 & 36 & -0.21 & -0.78 & -0.59 & 35.8 & 28.5 & 4.18 & 0.56 & 7.46 \\
\hline 5 & 357 & 20 & -0.05 & 0.94 & -0.34 & 152.9 & 26.5 & 1.59 & 0.55 & 2.89 \\
\hline 6 & 170 & 14 & 0.17 & -0.96 & -0.24 & 90.8 & 44.9 & 0.54 & 0.46 & 1.17 \\
\hline & & & & & & & & & $P_{32}$ (tot.) & 18.61 \\
\hline
\end{tabular}

Table 3. $P_{32}$ values per each MS.

Tabla 3. Valores $P_{32}$ para cada MS. 
careful analysis, a censoring of the smallest traces was reluctantly applied. The pattern in Figure 4 consists of more than 500 traces, of which 93 were specifically analysed to define the orientations on the digital photo. The macro-sets were defined by fuzzy cluster analysis (Hammah and Curran, 1998) using the Rocscience DIPS software with the relative mean normals and Fisher's constant. As the definition of the macro-sets excluded some discrete fractures, these spurious elements were discretionally associated to macro-sets. Finally, the cumulative trace length was computed for each macro-set; this value, divided by the area of the sampling window (equal to $3.5 \times 7$ square metres), is the $P_{21}$ for the macro-set. These values, together with the results obtained for $P_{32}$ by applying the correlation factor, are shown in Table 3. The total fracture intensity, i.e. considering all the macro-sets, is approximately 18 square metres per cubic metre of rock.

\section{Calculation of the NOA weight per unit volume}

The actual concentration of NOA minerals in theTimone outcrop was measured in samples obtained from three drill cores, roughly perpendicular to each other, from the same outcrop. Samples were ground and a representative portion of the obtained powder (about $16 \mathrm{~g}$ ) was analysed by SEM-EDS. Based on the results shown in Table 1, a weighted mean NOA concentration of $750 \mathrm{ppm}$ was assumed to be representative of the outcrop. This concentration, given a mean density of the serpentinite of $2750 \mathrm{~kg} / \mathrm{m}^{3}$, corresponds to a measured weight of NOA minerals of $2.063 \mathrm{~kg}$ per cubic metre of rock.

The obtained volumetric intensity $P_{32}$ was used to calculate the NOA weight per unit volume $\left(\mathrm{W}_{\mathrm{NOA}}\right)$ by multiplying it by several factors based on the assumption that not all fractures are mineralized and not all of a fracture surface is occupied by NOA minerals. These factors were estimated from outcrop observations and thin-section studies. The estimated $\mathrm{W}_{\mathrm{NOA}}$ is calculated as:

$$
W_{\mathrm{NOA}}=P_{32} c f_{1} c f_{2} c f_{3} t \delta_{\mathrm{NOA}}
$$

where $c f_{1}, c f_{2}, c f_{3}$ are, respectively, the proportion of fractures that are mineralized, the ratio of the mineralized surface to the total surface of a fracture, the ratio of NOA minerals to the total vein minerals, $t$ is the thickness of NOA-bearing veins and $\delta_{\mathrm{NOA}}$ is the NOA density, equal to the density of chrysotile $(2510 \mathrm{~kg} /$ $\left.\mathrm{m}^{3}\right) . P_{32}$ was obtained using the procedure mentioned above, which gave a value of $18 \mathrm{~m}^{2} / \mathrm{m}^{3}$. The values of $c f_{1}, c f_{2}, c f_{3}$ and $t$ are $0.7,0.5,0.5$ and $0.0004 \mathrm{~m}$, respec- tively. The estimated $\mathrm{W}_{\mathrm{NOA}}$ is approximately $3.16 \mathrm{~kg}$ per cubic metre of asbestiferous rock.

This result is in acceptable agreement with the NOA-content evaluation obtained by the direct measurement of $2.06 \mathrm{~kg} / \mathrm{m}^{3}$ and is particularly significant given the high variability of the asbestos distribution. The discrepancy between the two values is at least partly due to the fact that the calculation of NOA content by the indirect method required the introduction of a series of parameters ('correction factors') related to the distribution of NOA in fractures were estimated by direct observation of the fracture systems at different scales. These factors could be refined by more detailed meso- and micro-scopic studies based on additional case histories. This experimental test shows that the indirect method for the asbestos content in fractured rock masses, based on the statistical analysis and modelling of NOA-bearing fracture systems, is promising and could represent a valuable contribution to conventional direct methods (e.g., SEM-EDS quantitative analysis), which require time-consuming sample preparation and extensive analyses.

\section{Discussion and Conclusions}

An experimental test to compare the results of indirect and direct assessment of NOA content in fractured rocks was conducted on a serpentinite outcrop containing chrysotile-bearing fractures. The test showed a relatively good agreement between the NOA-content evaluation using an indirect assessment method (inference from fracture intensity modelling) and a direct method (quantitative SEM-EDS analysis of asbestos content). The test provided comparable values for the two methods $\left(3.16 \mathrm{~kg} / \mathrm{m}^{3}\right.$ vs. $2.06 \mathrm{~kg} / \mathrm{m}^{3}$ respectively). This first result bodes well for further analysis. It is particularly promising when the significant variability of the asbestos distribution within the rock masses, even within apparently homogeneous lithotypes (e.g., Labagnara et al., 2013), is taken into account. The calculation of NOA content by the indirect method required the introduction of a number of parameters ('correction factors') related to the distribution of NOA in fractures, which are estimated through direct observation at different scales. A refinement of the accuracy of these parameters, based on more detailed meso- and microscopic studies and using larger data sets, could further reduce the difference between the indirect and direct NOA content predictions.

This experimental test demonstrates the suitability of indirect methods for asbestos content assessment in fractured rock masses, based on the statistical analysis and modelling of NOA-bearing fracture systems. The 
indirect evaluation of NOA content in fractured rock masses could provide valuable support for traditional direct evaluation methods (e.g., SEM-EDS quantitative analysis), which require time-consuming sample preparation and analysis.

\section{References}

ASPI (Autostrade per I'Italia) 2011. Opera a mare nel canale di calma; parte descrittiva generale. APG9030, http:// www.va.minambiente.it/File/Documento/25374 (in italian).

Botta, S., Barale, L., Compagnoni, R., Cossio, R., Piana, F., Marcelli, I., Tallone, S., Avataneo, C., Turci, F. 2020. Petrofacies for the prediction of NOA content in rocks: application to the "Gronda di Genova" tunneling project. Bulletin of Engineering Geology and the Environment, 79(1), 185-204.

Capponi, G., Crispini, L. 2008. Carta Geologica d'Italia alla scala 1:50.000 e note Illustrative, Foglio 213-230 (Genova). APAT, Roma.

Capponi, G., Crispini, L., Federico, L., Malatesta, C. 2016. Geology of the Eastern Ligurian Alps: a review of the tectonic units. Italian Journal of Geosciences, 135(1), 157-169.

Cravero, M., Piana, F., Ponti, S., Tallone, S., Balestro, G., Morelli, M. 2006. Analysis of fracture patterns constrained by suitable geological model. 41st US Rock Mechanics Symposium. American Rock Mechanics Association, Golden, CO. ARMA/USRMS 06-1147 .

Crispini, L., Federico, L., Capponi, G., Spagnolo, C. 2009. Late orogenic transpressional tectonics in the "Ligurian Knot". Italian Journal of Geosciences, 128, 433-441.

Dershowitz W., Herda H. 1992. Interpretation of fracture spacing and intensity. 33rd U.S. Rock Mechanics Symposium, Santa Fe, New Mexico, 757-766.
Giacomini, F., Boerio, V., Polattini, S., Tiepolo, M., Tribuzio, R., Zanetti, A. 2010. Evaluating asbestos fibre concentration in metaophiolites: a case study from the Voltri Massif and Sestri-Voltaggio Zone (Liguria, NW Italy). Environmental Earth Sciences, 61, 1621-1639.

Groppo, C., Rinaudo, S., Cairo, D., Gastaldi, R., Compagnoni, R. 2006. Micro-Raman spectroscopy for a quick and reliable identification of serpentine minerals from ultramafics. European Journal of Mineralogy, 18(3), 319-329.

Hammah, R.E., Curran, J.H. 1998. Fuzzy cluster algorithm for the automatic identification of joint sets. International Journal of Rock Mechanics \& Mining Sciences, 35(7), 889-905.

Labagnara, D., Patrucco, M., Rossetti, P., Pellegrino, V. 2013. Predictive assessment of asbestos content in the Western Italian Alps: an essential tool for an effective approach to risk analysis in tunnelling operations and muck reuse. Environmental Earth Sciences, 70, 857-868.

Piana, F., Fioraso, G., Irace, A., Mosca, P., d'Atri, A., Barale, L., Falletti, P., Monegato, G., Morelli, M., Tallone, S., Vigna, G.B. 2017. Geology of Piemonte region (NW Italy, Alps-Apennines interference zone). Journal of Maps, 13(2), 395-405.

Rinaudo, S., Gastaldi, D., Belluso, E. 2003. Characterization of chrysotile, antigorite and lizardite by FT-Raman spectroscopy. Canadian Mineralogist, 41, 883-890.

Turci, F., Compagnoni, R., Piana, F., Delle Piane, L., Tomatis, M., Fubini, B., Tallone, S., Fuoco, S., Bergamini, M. 2015. Geological and analytical procedures for the evaluation of asbestos-related risk in underground and surface rock excavation. Engineering Geology for Society and Territory, Vol. 5, Springer, Berlin.

Wang, X. 2005. Stereological interpretation of rock fracture traces on borehole walls and other cylindrical surfaces. PhD Thesis, Virginia Polytechnic Institute and State University, Blacksburg, Virginia.

Recibido: julio 2019

Revisado: noviembre 2019

Aceptado: enero 2020

Publicado: marzo 2021 